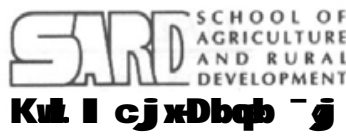

Available online at http:/ / www.banglajol.info/index.php/jard
J ARD

Journal of Agriculture \& Rural Development

\title{
Use of Duckweed as Feed for Fishes in Polyculture
}

\author{
A. N. M. A. KABIR ${ }^{1}$, M. A. HOSSAIN ${ }^{2 *}$ \& M. S. RAHMAN ${ }^{1}$ \\ ${ }^{1}$ Department of Fisheries Management, Bangladesh Agricultural University, Mymensingh-2202, \\ Bangladesh \\ ${ }^{2}$ Department of Fisheries, Bangabandhu Sheikh Mujibur Rahman Agricultural University, Gazipur- \\ 1706, Bangladesh
}

\begin{abstract}
Effect of duckweed supplementation as fish feed to polyculture system was investigated. Fish were reared for 90 days with or without duckweed supplementation. The ponds were fertilized with cowdung, urea and triple super phosphate. All the important physico-chemical factors including temperature, transparency, dissolved oxygen, total alkalinity, phosphate-phosphorus and nitratenitrogen were within productive ranges for fish culture. Ponds were stocked with silver carp, Thai sharputui, tilapia, common carp and mrigel. After a 90 days rearing period, net fish production was found to be significantly higher in fish fed duckweed at a rate of $20 \%$ of body weight compared to fish without duckweed supplement. It was concluded that duckweed can effectively be used as feed for polyculture of fish.
\end{abstract}

Key words: Duckweed, polyculture, feed.

\section{INTRODUCTION}

Duckweed are small floating aquatic plants, widely available in Bangladesh and consists of four genera viz. Lemna, Spirodela, Wolfilla and Wolffiella among which 40 species have been identified so far. Lemna minor is the most important species of Lemna (Journey et al., 1991). It can be grown abundantly with minimum cost and can be made available in much cheaper price than other alternative plant protein sources. Recently duckweed has been accepted as a protein rich (40-45\% of the dry weight) food for fish (Leng et al., 1995; Saha et al., 1999). Duckweed protein has higher concentration of essential amino acids, lysine and methionine, than most plant proteins and more closely resembles animal protein in that respect (Journey et al., 1991). There are some studies available on the use of duckweed as feed for fishes in monoculture but a little work have been carried out on its in polyculture. Considering the importance of duckweed use and development of future research on duckweed the present study was undertaken to evaluate effect of duckweed supplementation on the growth, survival and production of 5 species of fishes in polyculture together with its effects on the limnological conditions of the experimental ponds.

\footnotetext{
* Corresponding author: Associate Professor, Department of Fisheries, Bangabandhu Sheikh Mujibur Rahman Agricultural University, Gazipur-1706, Bangladesh, Tel. (02) 9205310-14 Ex. 2151, E-mail: m_amzad_hossain@hotmail.com

(C) 2009 School of Agriculture and Rural Development, Bangladesh Open University, All rights reserved.
} 
A. N. M. A. Kabir et al.

\section{MATERIALS ANd Methods}

\section{Experimental pond}

A series of 6 rectangular ponds of about $40 \mathrm{~m}^{2}$ of surface area and $0.7 \mathrm{~m}$ of water depth were used for the experiment. The bottoms of the ponds were plain with 6 inches mud. Bottom soil type was silt clay. All the ponds were completely independent having facility of water supply from a deep tube-well. The embankment was well protected and covered with grass. Three ponds were assigned for treatment I (with duckweed supply) and the other three for treatment II (control, without duckweed supply).

\section{Fertilization of pond}

Fertilization of pond was done fortnightly with cowdang, urea and triple super phosphate at the rate of $10 \mathrm{~kg} / \mathrm{dm}, 60 \mathrm{~g} / \mathrm{dm}$ and $90 \mathrm{~g} / \mathrm{dm}$, respectively. Cowdung was applied at four corners of each pond as bulky amount. Triple super phosphate and urea were mixed together, dissolved in a plastic bucket before 24 hours of application and applied by spreading on pond surface manually.

\section{Stocking fish}

After 7 days of fertilization, fingerlings of silver carp (Hypopthalmicthys molitrix), Thai sharpoti (Barbodes gonionotus), tilapia (Tilapia nilotica), common carp (Cyprinus carpio var communis) and mrigel (Cirrhinus cirrhosus) were stocked in all the ponds at the density of 80 fish per decimal and at the ratio of silver carp:tilapia:sharputi:mrigel:common carp= 20:20:20:10:10. The initial average weight of silver carp, mrigel, tilapia, sharputi and common carp was $10.10 \mathrm{~g}$. All the fingerlings were collected from a commercial nursery. Transportation of fingerlings was done carefully to minimize the stress and mortality. Proper conditioning (60 min.) was done before releasing the fingerlings in the experimental ponds. Rearing of fish was conducted for 90 days.

\section{Supply of duckweed as fish feed}

Duckweed were cultured in a separate pond and collected everyday for feeding experimental fish. Collected duckweed were weighed and supplied everyday to the fish of treatmet I at a rate of $20 \%$ of total body weight of fish.

\section{Study of water quality parameter}

During the study period the water quality parameters were recorded fortnightly. Transparency $(\mathrm{cm})$, water temperature $\left({ }^{\circ} \mathrm{C}\right), \mathrm{pH}$, dissoved oxygen $(\mathrm{mg} / \mathrm{L})$, total alkalinity $(\mathrm{mg} / \mathrm{L}), \mathrm{PO}_{4}-\mathrm{P}(\mathrm{mg} / \mathrm{L}), \mathrm{NO}_{3}-\mathrm{N}$ $(\mathrm{mg} / \mathrm{L})$, phytoplankton density (cells/L) and zooplankton density (cells/L) were recorded and estimated fortnightly with the standard methods.

\section{Statistical analysis}

T-test of net fish production of the ponds under treatment I and treatment II was done using SPSS statistical package programme.

\section{Results AND Discussion}

The results of physico-chemical parameters of experimental ponds are shown in Table 1 . All the physico-chemical parameters recorded during the experimental period were within the acceptable ranges for fish culture. Transparency (turbidity resulting from plankton) of water varied between 34.0 to $49.0 \mathrm{~cm}$. Rahman (1992) stated that the transparency of productive waterbodies should be $40 \mathrm{~cm}$ or less. Water temperature ranged between 29.0 to $32.0^{\circ} \mathrm{C}$. Ali et al. (1982) found that water temperature range of pond between 20.5 to $36.5^{\circ} \mathrm{C}$ was suitable for fish culture. Ranges of $\mathrm{pH}$, dissolved oxygen, total alkalinity, phosphate phosphorus and nitrate nitrogen found in both the treatments (Table 1) were suitable for fish culture (Rahman, 1992; Islam 1997).

Phytoplanktons population indicates the productive status of a waterbody, because these are the direct and basic sources of food for most of the organisms in aquatic habitat. In the present study, phytoplankton densities in treatment I and treatment II ranged between $4.7 \times 10^{4}$ to $5.8 \times 10^{4}$ 
cells/L and $4.4 \times 10^{4}$ to $5.7 \times 10^{4}$ cells/L, respectively. During the present study, ranges of zooplankton in ponds supplied with duckweed (treatment I) and without duckweed (Treatment II) were $7.7 \times 10^{3}$ cells $/ \mathrm{L}$ to $9.9 \times 10^{3}$ cells $/ \mathrm{L}$ and $7.0 \times 10^{3}$ cells $/ \mathrm{L}$ to $8.5 \times 10^{3}$ cells $/ \mathrm{L}$, respectively. These ranges of plankton were suitable for fish culture and similar to results obtained by Rashid (1999) and Israfil (2000).

Table 1. Fortnightly fluctuations of physical parameters of the ponds with supply of duckweed during the experimental period

\begin{tabular}{lccccccc}
\hline Parameter & Treatment & \multicolumn{7}{c}{ Sampling day } \\
\cline { 3 - 7 } & & 1 & 2 & 3 & 4 & 5 & 6 \\
\hline Water & T-I & 30.5 & 30.8 & 29.5 & 31.2 & 31.2 & 29.9 \\
temperature $\left({ }^{\circ} \mathrm{C}\right)$ & T-II & 31.65 & 31 & 30.2 & 31.55 & 29.7 & 31.05 \\
Transparency & T-I & 38.5 & 34 & 42.5 & 41.5 & 39.5 & 43 \\
$(\mathrm{~cm})$ & $\mathrm{T}-\mathrm{II}$ & 41.5 & 40.5 & 48.5 & 47 & 37.5 & 43 \\
$\mathrm{pH}$ & $\mathrm{T}-\mathrm{I}$ & 7.2 & 7.5 & 7.0 & 6.8 & 7.2 & 7.4 \\
& $\mathrm{~T}-\mathrm{II}$ & 7.1 & 6.85 & 6.9 & 7.55 & 7.2 & 6.95 \\
Dissolved & $\mathrm{T}-\mathrm{I}$ & 6.45 & 5.05 & 6.10 & 5.10 & 4.9 & 4.75 \\
oxygen $(\mathrm{mg} / \mathrm{L})$ & $\mathrm{T}-\mathrm{II}$ & 6.15 & 6.5 & 4.95 & 4.85 & 5.1 & 4.65 \\
Total alkalinity & $\mathrm{T}-\mathrm{I}$ & 97.5 & 65.0 & 68.5 & 68.0 & 78.5 & 61 \\
(mg/L) & $\mathrm{T}-\mathrm{II}$ & 80 & 72.5 & 58.5 & 66.5 & 58.5 & 105 \\
$\mathrm{PO}_{4}-\mathrm{P}(\mathrm{mg} / \mathrm{L})$ & $\mathrm{T}-\mathrm{I}$ & 0.73 & 0.78 & 0.60 & 0.51 & 0.52 & 0.43 \\
& $\mathrm{~T}-\mathrm{II}$ & 0.69 & 0.57 & 0.56 & 0.69 & 0.61 & 0.73 \\
$\mathrm{NO}_{3}-\mathrm{N}(\mathrm{mg} / \mathrm{L})$ & $\mathrm{T}-\mathrm{I}$ & 1.87 & 1.78 & 1.92 & 1.62 & 1.91 & 1.90 \\
& $\mathrm{~T}-\mathrm{II}$ & 1.87 & 1.62 & 1.68 & 1.68 & 1.44 & 1.58 \\
\hline
\end{tabular}

Table 2. Fortnightly fluctuations of the densities of phytoplankton and zooplankton of the experimental ponds during the experimental period

\begin{tabular}{lccccccc}
\hline \multicolumn{1}{c}{ Parameter } & Treatment & \multicolumn{7}{c}{ Sampling day } \\
\cline { 3 - 8 } & & 1 & 2 & 3 & 4 & 5 & 6 \\
\hline Phytoplankton $\left(\times 10^{3}\right.$, & T-I & 58.4 & 52.2 & 50.5 & 52.2 & 46.5 & 56.5 \\
cells/L) & T-II & 57.0 & 49.6 & 43.6 & 45.1 & 45.4 & 47.4 \\
Zooplankton $\left(\times 10^{3}\right.$, & T-I & 9.9 & 7.7 & 7.9 & 8.6 & 8.4 & 8.0 \\
cells/L) & T-II & 8.3 & 8.5 & 7.8 & 7.0 & 7.1 & 8.0 \\
\hline
\end{tabular}

Production of fish is shown in Table 3. After the 90 days of experimental period, net production of fish was $7.771 \mathrm{~kg} / \mathrm{dec}$ in treatment I (with supply of duckweed) and $5.923 \mathrm{~kg} / \mathrm{dec}$ in treatment 2 (without duckweed supplement). Percent increase of net production of fish of treatment I over treatment II were 31.25\%. Journey et al. (1991) found similar results. Culley (1976) found that dried duckweed are highly nutritive containing $20-40 \%$ crude protein, $6 \%$ fat and only $7-10 \%$ fiber and duckweed might be compete with classical protein crops like alfalfa and soybean. Kohinoor et al. (1999) observed the effectiveness of duckweed as a low-cost supplementary feed in a six months production trial on raj puti (Barbodes gononionotus) with carp. They stated that duckweed would be a low-cost supplementary feed, particularly for farmer with limited income. Most of the physico-chemical parameters of the ponds under treatment I and treatment II were similar but production of fish in the ponds with duckweed supplementation were higher than those in the ponds without duckweed supplement. The results indicated that duckweed supplement positively influenced the growth of experimental fishes. T-test of net production showed that diffrence between treatment I and treatment II was statistically significant $(p<0.05)$ i.e. influence of duckweed on production of fish was positively significant. In fine, it may be concluded that duckweed may be preferable food item for fishes at least the fishes under experiment and can effectively be used as low-cost feed for their polyculture. 
A. N. M. A. Kabir et al.

Table 3. Initial and final weight of fishes under treatment I and treatment II after 90 days rearing period

\begin{tabular}{|c|c|c|c|c|c|}
\hline Treatment & Fish species & $\begin{array}{l}\text { Initial total wt. } \\
\text { of } \mathrm{sp} .(\mathrm{g} / \mathrm{dec})\end{array}$ & $\begin{array}{l}\text { Final total wt. } \\
\text { of } \mathrm{sp} .(\mathrm{kg} / \mathrm{dec})\end{array}$ & $\begin{array}{l}\text { Net production of } \\
\text { the sp. }(\mathrm{kg} / \mathrm{dec})\end{array}$ & $\begin{array}{c}\text { Percent } \\
\text { increase* }\end{array}$ \\
\hline \multirow{6}{*}{$\begin{array}{l}\text { Treatment I } \\
\text { (with supply } \\
\text { of duck } \\
\text { weed) }\end{array}$} & Silver carp & 250 & 3.000 & 2.750 & $4.76 \%$ \\
\hline & Mrigal & 110 & 1.050 & 0.940 & $2.17 \%$ \\
\hline & Sharputi & 175 & 1.625 & 1.450 & $68.80 \%$ \\
\hline & Tilapia & 180 & 1.850 & 1.670 & $87.85 \%$ \\
\hline & Common carp & 95 & 1.056 & 0.961 & $54.54 \%$ \\
\hline & Total & 810 & 8.581 & 7.771 & $31.20 \%$ \\
\hline \multirow{6}{*}{$\begin{array}{l}\text { Treatment II } \\
\text { (without } \\
\text { supply of } \\
\text { duck weed) }\end{array}$} & Silver carp & 250 & 2.875 & 2.625 & \\
\hline & Mrigal & 110 & 1.030 & 0.920 & \\
\hline & Sharputi & 175 & 1.034 & 0.859 & \\
\hline & Tilapia & 180 & 1.069 & 0.889 & \\
\hline & Common carp & 95 & 0.725 & 0.630 & \\
\hline & Total & 810 & 6.733 & 5.923 & \\
\hline
\end{tabular}

*percent increase of production of the sp. of treatment I over treatment II (control).

\section{Literature Cited}

Ali, S., Rahman, A.K.A., Patwary, A.R. and Islam, K.H.R. 1982. Studies on diurnal variation in physico-chemical factors and zooplankton in freshwater pond. Bangladesh J Fish 2-5(1-2), 1523.

Culley, D.D. Jr. 1976. Making Aquatic Weeds Useful. National Academy of Science, Washington D.C., $144-150$ pp.

Islam, M.N. 1997. Effect of Nitrogen Fertilizer on the Production of Lemna minor. MS Thesis, Bangladesh Agricultural University, Mymensingh, $93 \mathrm{p}$.

Israfil, M. 2000. Effect of Periphyton on Monoculture of That Sharputi (Puntius gonionotus). MS Thesis, Bangladesh Agricultural University, Mymensingh. 105 p.

Journey, T., Skillikorn, P. and Spira, B. 1991. Duckweed Aquaculture: A New Farming System for Developing Countries. Emena Tec. Department, World Bank. 125 p.

Kohinoor, A.H.M., Islam, M.S., Begum, N. and Hussain, M.G. 2001. Production of Thai sharputi (Puntius gonionotus Bleeker) in polyculture with carps using low-cost feed. Bangladesh J Fish Res 3(2), 157-164.

Leng, R.A., Stambolie, J.H. and Bell, R. 1995. Duckweed- a potential high-protein feed resource for domestic animals and fish. AAAP Conf. Proc., Bali, pp. 103-114.

Rahman, M.S. 1992. Water Quality Management in Aquaculture. BRAC Prokashana, Mohakhali, Dhaka, Bangladesh, $84 \mathrm{p}$.

Rashid, M.M. 1999. Effects of periphyton on monoculture of Labeo gonius. MS Thesis, Bangladesh Agricultural University, Mymensingh, Bangladesh, $78 \mathrm{p}$.

Saha, J.K., Rahmatullah, S.M. and Mazid, M.A. 1999. Optimization of stocking density of duckweed, Wolffia arrhiza (Linn) and Lemna sp. Bangladesh J Fish Res, 1(2), 45-53. 